\title{
Zastosowanie podejścia procesowego w zarządzaniu publicznymi szkołami wyższymi - wyzwania teorii i praktyki
}

\begin{abstract}
STRESZCZENIE. Wyzwaniem dla szkoły wyższej w XXI wieku stają się: jakość usług oraz skuteczność, efektywność i elastyczność działania. W odpowiedzi na nie szkoły dokonują restrukturyzacji systemów zarządzania, wdrażając nowoczesne koncepcje i metody oparte na podejściu procesowym, takie jak: TQM, w tym EFQM, ISO 9001, Lean Management, Six Sigma, reengineering, benchmarking, outsourcing, centra usług wspólnych. Celem artykułu jest prezentacja dotychczasowego dorobku teoretycznego oraz praktycznego z zakresu problematyki wykorzystania koncepcji i metod zarządzania opartych na podejściu procesowym w zarządzaniu szkołami wyższymi. Artykuł jest oparty na analizie literatury przedmiotu oraz badaniach własnych w zakresie wdrażania podejścia procesowego w szkołach wyższych. Efektem jest wskazanie na podstawowe kwestie podejmowane w badaniach, przesłanki i bariery oraz luki badawcze w tym obszarze.
\end{abstract}

SŁOWA KLUCZOWE: podejście procesowe, szkoły wyższe, New Public Management, good governance

\section{Wstęp}

W sytuacji ograniczenia funduszy publicznych, rosnącej konkurencji, wprowadzania do zarządzania publicznego orientacji rynkowej oraz wymogu transparentności oczekuje się, że system zarządzania uczelnią będzie spełniał postulaty skuteczności, efektywności, elastyczności oraz jakości. Przydatność tradycyjnych zbiurokratyzowanych funkcjonalnych struktur zarządzania wyczerpuje się i dezaktualizuje, gdyż coraz bardziej komplikują i wydłużają one realizację działań oraz całościową optymalizację organizacji (Grajewski 2012: 20), obniżając jej skuteczność, efektywność, elastyczność oraz zdolność do tworzenia wartości. Uniwersytety w coraz większym stopniu są traktowane jako organizacje sektora publicznego, a w coraz mniejszym stopniu jako tradycyjne, historycznie wyjątkowe instytucje akademickie (Kwiek 
2015: 23). Na fali neoliberalizmu oraz menedżeryzmu wdraża się kocepcję New Public Management oraz tworzy sieci współpracy w myśl idei good governance (Sześciło 2015: 34). Obserwuje się odchodzenie szkół wyższych od modelu uniwersytetu liberalnego w kierunku modelu uniwersytetu przedsiębiorczego (Leja 2013: 32-38; Antonowicz 2005: 156-159).

Celem artykułu jest prezentacja dotychczasowego dorobku teoretycznego oraz praktycznego z zakresu wykorzystania koncepcji i metod zarządzania szkołami wyższymi opartych na podejściu procesowym. W artykule stawia się pytanie: czy podejście procesowe jest koncepcją zarządzania, która może skutecznie wspierać kierownictwo uczelni w realizacji jej strategicznych i operacyjnych celów? Tak postawione pytanie badawcze implikuje pytania szczegółowe: Jakie procesowe metody i techniki zarządzania są wdrażane przez szkoły wyższe? Jakie są wnioski z prowadzonych wdrożeń (przesłanki, bariery, sukcesy)? Jakie luki badawcze są w tym zakresie?

Artykuł jest oparty na analizie literatury przedmiotu oraz badaniach własnych w zakresie wdrażania podejścia procesowego w szkołach wyższych.

\section{Istota podejścia procesowego w zarządzaniu szkołami wyższymi}

Idea podejścia procesowego do zarządzania organizacją pojawiła się już na początku XX wieku w pracach prekursorów zarządzania: Frederica Taylora (Davenport 2008: XIV) i Karola Adamieckiego (Lisiecka i Maciąg 2007: 87-91). Zarządzanie procesami u początków swojego istnienia dotyczyło głównie procesów produkcyjnych, jednak z czasem zaczęło być również stosowane w procesach pozaprodukcyjnych i organizacjach usługowych. Za sprawą publikacji Michaela Hammera i Jamesa Champy'ego (1997) w latach 80. narodziła się koncepcja Business Proces Reengineering, która zakładała radykalne przeprojektowanie organizacji według podejścia procesowego. Jak podkreśla Thomas H. Davenport (2008: XVI), modna w europejskich i amerykańskich przedsiębiorstwach XX wieku koncepcja, która była wdrażana często wybiórczo i krótkotrwale, stała się obecnie wymogiem skutecznego i efektywnego działania nowoczesnej organizacji XXI wieku. Zarządzanie procesowe z poziomu operacyjnego stało się strategiczną koncepcją zarządzania organizacją.

W podejściu procesowym organizację rozpatruje się jako układ wzajemnie powiązanych procesów (powiązania rzeczowe, finansowe, informacyjne, personalne), przy czym posiadają one swoją hierarchię ${ }^{1}$. Procesowe zarządzanie organizacją po-

${ }^{1}$ Proces można zdefiniować jako logiczną organizację zasobów organizacji (rzeczowych, finansowych, informacyjnych i ludzkich) oraz przebiegów czynności (działań), które są skierowane na 


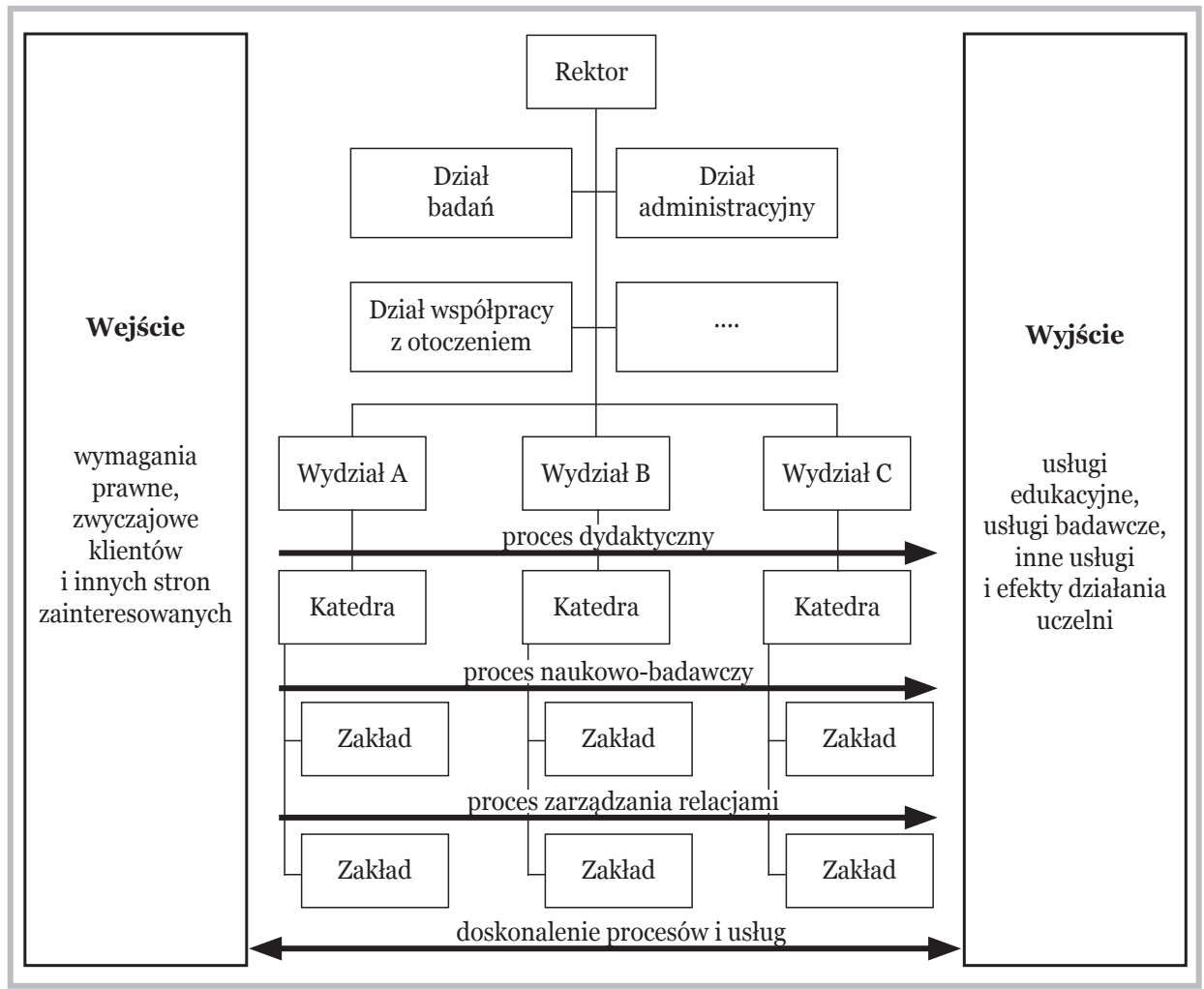

Rysunek 1. Model systemu zarządzania szkołą wyższą według podejścia procesowego

Źródło: opracowanie własne.

lega na takim ukształtowaniu relacji wewnątrzorganizacyjnych, aby uzyskać efekt dynamizmu działania systemu poprzez optymalizację wyodrębnionych w nim procesów (Grajewski 2012: 23). Celem stosowania podejścia procesowego jest zatem optymalizacja systemu zarządzania poprzez minimalizację lub eliminację tych czynności lub działań, które są nieefektywne i nie zwiększają wartości tworzonej w procesie dla klienta ${ }^{2}$. Rysunek 1 prezentuje koncepcyjny model systemu zarządzania uczelnią według podejścia procesowego.

osiągnięcie wyniku zgodnego z wymaganiami i oczekiwaniami klienta, zarówno wewnętrznego, jak i zewnętrznego. Zgodnie z terminologią przyjętą w normie ISO 9000:2015 proces jest to zbiór działań wzajemnie powiązanych lub wzajemnie oddziałujących, które przekształcają wejścia w wyjście (Grajewski 2007: 55; Norma PN-EN ISO 9000:2015 PKN 2016).

${ }^{2}$ Klienta rozumie się jako klienta wewnętrznego (pracownika organizacji) oraz klienta zewnętrznego (klientów i inne strony zainteresowane działaniem organizacji). 
Procesy realizowane w szkole wyższej są złożone i zhierarchizowane. Najczęściej stosowanym kryterium ich podziału jest udział w tworzeniu wartości dla klienta (Hamrol 2007: 113-112). Można wyróżnić procesy podstawowe, prowadzące do powstawania wartości produktów i usług, będące źródłem dochodów i zysków dla szkoły (m.in. proces dydaktyczny, proces naukowo-badawczy, proces zarządzania relacjami z otoczeniem). Na wejściu i wyjściu tych procesów znajduje się klient zewnętrzny (student, kandydat, rodzic, państwo, przedsiębiorstwa, samorządy i inne podmioty, z którymi współpracuje uczelnia), który ma określone wymagania i jest gotów zapłacić za efekt procesu (usługa edukacyjna, usługa badawcza i in.). Druga grupa procesów to procesy wpierające, które towarzyszą procesom podstawowym, dostarczają danych i informacji lub regulują ich działanie, mają charakter regulacyjny i decyzyjny, zazwyczaj nie prowadzą do powstawania wartości dodanej. W uczelni do takich procesów można zaliczyć: planowanie strategiczne, zarządzanie zaopatrzeniem, zarządzanie personelem i środowiskiem pracy, zarządzanie finansami, zarządzanie infrastrukturą, zarządzanie wiedzą i informacją ${ }^{3}$. Wdrożenie podejścia procesowego w szkole wyższej wymaga:

- przełożenia celów strategicznych uczelni na cele poszczególnych procesów oraz komunikacji w zakresie stopnia ich realizacji (komunikacja dwustronna pionowa - naczelne kierownictwo - właściciele procesów ${ }^{4}$ oraz wielostronna komunikacja pozioma w procesach);

- przeglądu i uporządkowania wewnętrznych aktów prawnych uczelni zgodnie z opisem realizowanych procesów;

- identyfikacji procesów i ich hierarchizacji (określenie dostawców i nakładów niezbędnych do realizacji procesu, w tym pracowników), określenia parametrów oceny jakości nakładów z uwagi na cel procesu (wskaźniki ilościowe, np. liczba pracowników, i jakościowe, np. poziom kompetencji), określenia czynności i działań w procesie, ich kolejności i powiązań, wraz z dokumentacją (instrukcje, regulaminy, procedury itp.), określenia mierników oceny skuteczności i efektywności procesu (np. czas, koszty, ilość działań, zadowolenie klienta, poziom błędów), określenia efektów - produktów procesu, ich odbiorców oraz mierników oceny ich jakości (najważniejszym miernikiem w procesach podstawowych jest satysfakcja klienta);

${ }^{3}$ Do hierarchizacji procesów w systemie zarządzania uczelnia może wykorzystać gotowe standardy, np. uniwersalną klasyfikację procesów APQC (American Quality Productivity Center) Process Classification Framework (PCF). Process Classification Framework version 6.1.1.American Quality Productivity Center. http://www.apqc.org/knowledgebase/download/313690/Ko5162_PCF_Ver_ 6\%201_1.pdf [7.02.2015].

${ }^{4}$ Właścicielem procesu może być: prodziekan ds. kierunku kształcenia, kierownik projektu badawczego, kierownik działu finansowego, kierownik infrastruktury. 
- konfiguracji procesów w perspektywie klienta - punktem wyjścia w projektowaniu procesów w organizacji jest klient zewnętrzny, jego wymagania i oczekiwania;

- przydzielenia odpowiedzialności i uprawnień w ramach procesów (określenie właścicieli procesów, odpowiedzialności i uprawnień decyzyjnych) oraz ustalenie powiązań między procesami w systemie zarządzania szkołą;

- uwzględnienia określonych rodzajów ryzyka i szans w realizacji procesów (PN-EN ISO 9001:2015 2016) (zarządzanie ryzykiem)5;

- doskonalenia wiedzy i kompetencji pracowników w realizacji działań oraz wiedzy o procesach (ważne jest też, aby pracownik był świadomy swojej roli w procesach);

- oceny i doskonalenia procesów poprzez wdrażanie niezbędnych zmian w celu zwiększania zdolności procesów do spełniania wymagań klienta i dostarczania wartości (podstawowe narzędzia oceny procesów to: zewnętrzne i wewnętrzne audyty, samoocena oraz benchmarking procesowy).

Zastosowanie podejścia procesowego daje możliwość stawienia czoła wyzwaniom w zarządzaniu współczesnymi organizacjami publicznymi na fali New Public Management oraz good governance. W tabeli 1 przeanalizowano najważniejsze wyzwania dla publicznych szkół wyższych oraz możliwości wykorzystania podejścia procesowego do restrukturyzacji ich systemów zarządzania.

Efektem wdrożenia podejścia procesowego może być:

- optymalne dopasowanie do wymagań zmiennego otoczenia,

- skuteczność, efektywność i elastyczność procesów uczelni, w tym ograniczanie ryzyka,

- ciągłe doskonalenie procesów tworzenia wartości dla klientów i interesariuszy uczelni.

Oparcie systemu zarządzania na procesach czyni szkołę wyższą bardziej stabilną i odporną na ryzyko. Może również dostarczyć instrumentarium pomocnego we wdrażaniu modelu uniwersytetu przedsiębiorczego.

\section{Koncepcje, metody i techniki zarządzania oparte na podejściu procesowym wdrażane w szkołach wyższych}

Analiza literatury przedmiotu wskazuje na przydatność zastosowania w praktyce działania szkół koncepcji i metod zarządzania opartych na podejściu procesowym, takich jak: TQM (w tym metod i narzędzi zarządzania jakością, np. systemu zarządzania jakością zgodnie z wymaganiami norm ISO serii 9000), Lean Management,

${ }^{5}$ Standardy zarządzania ryzykiem są obligatoryjne w jednostkach publicznych w ramach kontroli zarządczej. Ustawa z dnia 27 sierpnia 2009 r. o finansach publicznych, Dz.U. nr 157, poz. 1240, art. 68. 







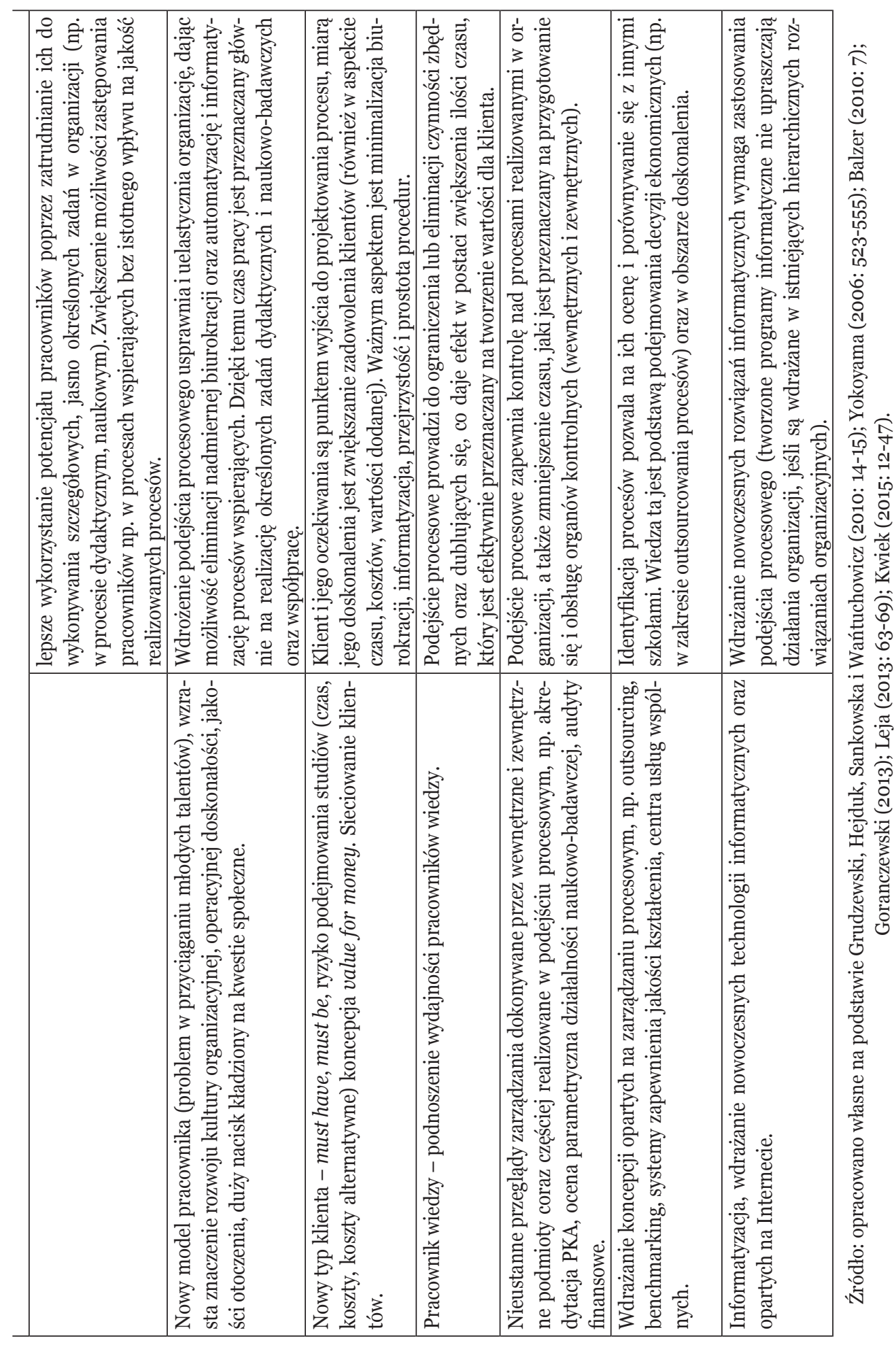


Six Sigma, reengineering, oraz wykorzystujących podejście procesowe, takie jak: benchmarking, outsourcing czy centra usług wspólnych. Poniżej zostanie dokonany przegląd wyników badań dotyczących wdrażania podejścia procesowego w szkołach wyższych.

\subsection{TQM (Total Quality Management - Kompleksowe Zarządzanie Jakością) ${ }^{6}$}

Pierwsze teoretyczne wzmianki na temat możliwości wykorzystania TQM w szkołach wyższych pojawiły się już w 1991 r. (np. Sherr i Lozier 1991), od 2002 r. zaś zaczęły ukazywać się artykuły prezentujące wyniki badań empirycznych prowadzonych w tym zakresie w szkołach wyższych (np. Osseo-Asare i Longbottom 2002). Badania skupiają się na trzech kwestiach: 1) wdrażaniu zarządzania jakością, 2) modelach, technikach i narzędziach zarządzania jakością, 3) wymiarach zarządzania jakością (Tarí i Dick 2012). Wskazuje się na przydatność następujących modeli i koncepcji zarządzania jakością bazujących na TQM: EFQM (European Foundation for Quality Management), MBNQA (Malcolm Baldrige National Quality Award), systemu zarządzania jakością opartego na wymaganiach norm ISO serii 900o. Podkreśla się również, że na potrzeby szkół wyższych tworzy się własne modele jakości oparte na TQM: EQUIS (The European Quality Improvement System), ENQA (The European Network for Quality Assurance in Higher Education), krajowe zewnętrzne systemy zapewniania jakości kształcenia, lub adaptuje się istniejące, np. Malcolm Baldrige Criteria for Performance Excellence for Education (Taria, Madeleine 2012, s. 790).

Najważniejsze kwestie podejmowane w badaniach to identyfikowanie i definiowanie wymiarów TQM oraz proponowanie i testowanie narzędzi do ich pomiaru. Do głównych czynników sukcesu we wdrażaniu TQM zalicza się: przywództwo, wizję, pomiary i ocenę, kontrolę procesów i doskonalenie, projektowanie programów, system doskonalenia jakości, zaangażowanie pracowników, docenianie i nagradzanie, edukację i szkolenia, skupienie się na klientach i interesariuszach (Bayraktar, Tatoglu i Zaim 2008: 551-574).

Ważnym zagadnieniem w badaniach są bariery wdrażania TQM. Są one wspólne dla organizacji wdrażających tę koncepcję, jednak zarządzanie szkołami wyższymi powoduje ograniczenia i bariery specyficzne, takie jak:

${ }^{6}$ Kompleksowe Zarządzanie Jakością (Total Quality Management) jest definiowane jako filozofia zarządzania oparta na zasadach przywódczej roli kierownictwa w organizacji, w której każdy pracownik współpracuje z zespołem ze swego środowiska pracy, stosując narzędzia ciągłej poprawy spełniania lub przekraczania oczekiwań klienta celem osiągnięcia przez instytucję korzyści rynkowych i ekonomicznych, wzrost zaufania pracowników do systemu zarządzania organizacją i zwiększanie produktywności przez wykorzystanie ich przywiązania i inwencji w poprawę cykli, kosztów i parametrów przebiegów procesów (Wasilewski 1998: 2). 
- trudności pomiaru rdzenia procesów uczenia się,

- trudności w kontrolowaniu procesu dydaktycznego w uczelni ze względu na różnorodność produktów, miejsc dostawy, sposobów dostarczania, procesów i personelu, które powinny być kontrolowane,

- brak odpowiedzialności zarządzających za jakość,

- brak upełnomocnienia pracowników do poprawy jakości,

- brak standardów, które odzwierciedlają wymagania klienta,

- wolność akademicka,

- trudności z określeniem, kim są klienci,

- trudności w określaniu produktu uczelni,

- nieregularne zobowiązania do nauczania i konflikt z zadaniami badawczymi (Tarí i Dick 2012; Davies 2000: 13; Bonstingl 1995).

Badania prowadzone w Portugali wskazują, że wdrażanie systemów zapewnienia jakości w niewielkim stopniu wpływa na zmianę kultury akademickiej. Procesy zapewnienia jakości nie wzbudzają dużego zainteresowania wśród pracowników akademickich, nie zmieniają ich przekonań i wartości, pracownicy nie są przekonani, że raporty samooceny i audyty faktycznie stanowią przedmiot analizy, a brak zaangażowania naukowców wywołuje sprzeciw wobec istnienia wewnętrznych procesów zapewniania jakości (Veiga, Rosa, Dias i Amaral 2013: 467). Podkreśla się, że sukces TQM zależy od dojrzałości kultury jakości i dostępności zasobów w połączeniu ze świadomością różnic kulturowych w inicjatywach jakości (Tarıa i Madeleine 2012: 801). Ważnym aspektem jest też jakość przywództwa i jakość zarządzania (Wawak 2012: 81).

Kolejnym obszarem badań jest ocena skuteczności i efektywności TQM (Maciąg 2011a; 2013). Postuluje się, aby modele oceny w większym zakresie uwzględniały badanie efektywności, w tym kryteria i mierniki finansowe oraz efekty tworzone dla interesariuszy szkoły (Tarí i Dick 2012).

Badania obejmują również wykorzystanie modelu $\mathrm{EFQM}^{7}$ w szkołach wyższych, które może być traktowane jako narzędzie wdrażania zmiany. Wyniki badań prowadzonych przez Taria i Madeleine (2012: 801) wskazują, że metodyka samooceny według EFQM musi być dostosowana do specyfiki i kontekstu działania szkoły. Bariery wdrażania samooceny oraz zmian z niej wynikających mogą się różnić między krajami (może to dotyczyć dostępności zasobów oraz braku zrozumienia i zaangażowania w inicjatywy i zmiany jakościowe ze strony części kierownictwa, szczególnie w przypadku krajów rozwijających się oraz takich, gdzie brakuje nacisku politycznego na tego typu zmiany). Kultura danego państwa, w tym promocja i tradycja kultury jakości, oraz poziom dojrzałości zarządzania mogą stanowić ba-

7 Model oceny został stworzony przez Europejską Fundację Zarządzania Jakością (European Foundation for Quality Management EFQM). Model doskonałości oparty jest na ośmiu zasadach i określa ramy funkcjonowania organizacji oparte na wymaganiach uporządkowanych w dziewięciu kryteriach sklasyfikowanych jako „nakłady” i „rezultaty” organizacji. Szerzej: http://www.efqm.pl/. 
rierę we wdrażaniu zmian jakościowych. Zaangażowanie kierownictwa oraz zasoby są głównymi czynnikami sukcesu wdrażania EFQM. Badania pokazują, że EFQM powoduje w szkołach wyższych następujące zmiany: nowe słownictwo i system pojęciowy, środowisko partycypacyjne, wdrażanie działań doskonalących (Tarıa i Madeleine 2012, s. 800).

Analiza przypadków prezentowanych w literaturze przedmiotu wskazuje na liczne korzyści, które są wynikiem wdrażania systemu zarządzania jakością zgodnego z normą ISO 90018. Jednak zmianom tym towarzyszą bariery o charakterze kulturowym, społecznym, technicznym i organizacyjnym (Wawak 2011; Maciąg 2011a; Piasecka 2011; Chalaris, Chalaris, Gritzalis i Belsis 2015; Goranczewski 2011). Sukces systemu zarządzania jakością jest w mniejszym stopniu uwarunkowany rygoryzmem wdrażania wymagań normy ISO 9001, a w większym - udziałem interesariuszy oraz tym, jak oni rozważają i interpretują system (Chalaris i in. 2015: 268).

\subsection{Lean Management}

Pierwsze dyskusje na temat wykorzystania koncepcji Lean Management w edukacji zostały podjęte w $1995 \mathrm{r}$. w związku z omawianiem problematyki przywództwa w TQM oraz możliwości ograniczenia kosztów poprzez eliminację marnotrawstwa w instytucjach edukacyjnych (Suarez-Barraza, Smith, Dahlgaard-Park 2012: 370). Koncepcja Lean jest obecnie jednym z ważnych wątków podejmowanych w procesie reformowania szkół wyższych, o czym świadczą coraz liczniejsze przykłady wdrożeń na całym świecie9. Dla podkreślenia specyfiki Lean w szkołach wyższych Balzer zaproponował określenie Lean Higher Education (LHE) (Balzer 2010). Obszary badań w zakresie wdrażania Lean Management obejmują m.in. identyfikację źródeł marnotrawstwa, mając na uwadze specyfikę szkoły wyższej i realizowanych w niej procesów (Douglas, Douglas i Anthony 2013: 17; Maciąg 2016a: 51-64). Praktyczne doświadczenia we wdrażaniu koncepcji Lean w szkołach wyższych potwierdzają, iż można osiągnąć w ten sposób wiele pozytywnych efektów, takich jak: zmiany w kulturze w różnych obszarach uczelni, upodmiotowienie pracowników (pozwalając im w ten sposób na podejmowanie kluczowych decyzji i wprowadzanie zmian w swoich procesach biznesowych); umożliwienie uczelni bycia organizacją elastyczną i uczącą się poprzez szybkie rozwiązania i sukcesy, uwolnienie potencjału pracowników w zakresie poprawy procesów poprzez ich zaangażowanie w procesy wewnętrzne (Thomas, Francis, Fisher i Chilton 2013: 137; Radnor i Bucci 2011: 23). Badania pilotażowe prowadzone przeze mnie w 2016 r. wskazują, że wdrożenie

\footnotetext{
${ }^{8}$ ISO 9001:2015 Quality management systems - Requirements (polski odpowiednik PN-EN ISO 9001:2016 Systemy zarządzania jakością - Wymagania).

${ }_{9}$ Lista szkół wdrażających koncepcję Lean znajduje się na stronie: http://www.leanhehub.ac.uk.
} 
systemu zarządzania jakością zgodnego z wymaganiami normy ISO 9001 istotnie wpływają na zmiany w kulturze organizacyjnej w kierunku kultury Lean (dotyczy to szczególnie takich aspektów, jak: ludzie i partnerstwa oraz procesy $)^{10}$.

\subsection{Six Sigma ${ }^{11}$}

Six Sigma ze statystycznej techniki pomiaru stała się filozofią zarządzania opartą na odpowiedniej kulturze organizacyjnej oraz zaangażowaniu kierownictwa (Tjahjono i in. 2010: 219; Bandyopadhyay i Lichtman 2007: 805). W literaturze przedmiotu można odnaleźć różne podejścia do wykorzystania Six Sigma. Proponuje się zastosowanie tej koncepcji w połączeniu z TQM do doskonalenia procesów administracyjnych w szkole wyższej (Campatellia, Cittib i Meneghina 2011), oceny procesu kształcenia, szczególnie w zakresie otrzymywania informacji zwrotnej (Yu i Ueng 2012), do projektowania programów kształcenia w celu zmniejszenie czasu pracy na przygotowanie materiałów i zwiększenie efektów kształcenia (Yeung 2013: 101), podkreśla się, iż wdrażanie Six Sigma wymaga pracy zespołowej, włączenia pracowników oraz studentów (Kukreja, Ricks i Meyer 2009). Warunkiem zastosowania Six Sigma jest budowa odpowiedniego, czasami kosztownego, systemu pomiarowego w szkole (Antony 2004: 303). Jest to przy tym proces czasochłonny, który może kolidować z obowiązkami dydaktycznymi i naukowo-badawczymi wykładowców (Kukreja i in. 2009: 23).

\subsection{Lean Six Sigma (LSS)}

Koncepcję Lean Management coraz częściej łączy się z Six Sigma. Badania w tym obszarze prowadzone w szkołach wyższych dotyczą następujących kwestii: badanie cech i kompetencji przywódców najbardziej potrzebnych we wdrażaniu Lean Six Sigma w szkołach wyższych (jako najważniejsze wskazuje się: umiejętność zarządzania zmianą i nieustannym doskonaleniem oraz budowanie zespołów i przekazywanie odpowiedzialności (Anthony 2013: 8). Wdrożenie koncepcji wymaga pełnej integracji sfery administracyjnych usług wewnętrznych ze sferą akademicką (Yorkstone 2013: 40). Podkreśla się, że pełna adaptacja koncepcji LSS w szkołach wyższych jest niemożliwa bez odpowiedniej kultury organizacyjnej oraz przywództwa (Jones 2013: 51).

${ }^{10}$ Badania pilotażowe zrealizowane wśród pracowników pięciu szkół wyższych zlokalizowanych w Polsce południowej techniką ankiety internetowej oraz papierowej (Maciąg 2016b).

${ }^{11}$ Celem Six Sigma jest doskonalenie procesów poprzez redukcję ich zmienności z wykorzystaniem metod statystycznych opartych na pomiarze odchylenia standardowego (kluczowym pojęciem jest poziom Six Sigma) (Hamrol 2007: 81; Antony 2004: 303). 


\subsection{Benchmarking}

Benchmarking procesowy znajduje coraz szersze zastosowanie w szkołach wyższych. Wykorzystywany jest do porównywania skuteczności i efektywności realizacji procesów naukowo-badawczych (Nicholls 2007: 539-562), dydaktycznych, np. ocena wykładowców oraz programów nauczania za pomocą RateMyProfessors.com (Wilson 2015), procesów administracyjnych w uczelni, takich jak: usługi wspierające studentów, usługi wspierające badania, księgowość, zarządzanie zasobami ludzkimi, logistyka i zaopatrzenie (Arena, Arnaboldi, Azzone i Carlucci 2009: 245), systemu kontroli zarządczej (Woźnicki 2012). Benchmarking traktuje się też jako element zarządzania wiedzą w organizacji (Kerr i Hosie 2013: 60) oraz organizacji uczącej się (Kuźmicz 2015: 206). Warunkiem efektywnego zastosowanie tego narzędzia jest odpowiedni dobór kryteriów oceny, mierników oraz narzędzi pomiaru, tak by można było przeprowadzić porównanie między procesami i podmiotami. K. Subrahmanya Bhat i Jagadeesh Rajashekhar wskazują, iż brak benchmarkingu jest jednym z głównych powodów niepowodzenia we wdrażaniu TQM w szkołach wyższych (Bhat i Rajashekhar 2009: 261-272).

\subsection{Outsourcing i insourcing}

Uczelnie wykorzystują w restrukturyzacji procesowej głównie metodę outsourcingu, zlecając na zewnątrz usługi w zakresie: ochrony obiektów (83\% uczelni), sprzątania, dozoru (portiernie, recepcje) (67\% uczelni), konserwacji, drobnych napraw (50\% uczelni), utrzymania zieleni, usług informatycznych (33\% uczelni) (Maciąg 2011b). Mając na uwadze wady wykorzystania outsourcingu w odniesieniu do procesów w szkołach wyższych, wskazuje się na przydatność selektywnego zaopatrzenia (selective sourcing) opartego na wykorzystaniu outsourcingu, business process outsourcingu, insourcingu, tworzeniu własnych organizacji na bazie wydzielonych procesów, świadczących usługi dla uczelni i innych odbiorców (internal market) oraz sojuszy strategicznych (Bulchand-Gidumal i Melian-Gonzalez 2010: 206). Prowadzone badania wskazują, że w zakresie usług ICT najbardziej odpowiednim rozwiązaniem jest tworzenie własnych organizacji na bazie wydzielonych procesów (Bulchand-Gidumal i Melian-Gonzalez 2010: 214).

\subsection{Centra usług wspólnych}

Koncepcja centrów usług wspólnych narodziła się w latach 80. w USA. Jej idea polega na usprawnianiu procesów poprzez przeniesienie powtarzalnych i podobnych działań administracyjnych oraz informatycznych realizowanych w organizacji do jednej jednostki - centrum usług wspólnych (dotyczy to przede wszystkim proce- 
sów zarządzania zasobami ludzkimi, finansowych, informatycznych, marketingu, audytów, zarzadzania infrastrukturą itp.). Jego podstawową korzyścią jest ograniczenie kosztów administracyjnych (Azzis 2016) ${ }^{12}$. Centra usług wspólnych stosowane są przede wszystkim w uczelniach w USA, krajach Europy Zachodniej i Północnej (m.in. Holandia, Finlandia, Belgia, Dania, Wielka Brytania).

Przeprowadzona analiza pokazuje, że wzrasta zainteresowanie wdrażaniem koncepcji i metod zarządzania procesowego w szkołach wyższych na świecie i w Polsce. W badaniach wskazuje się kluczowe czynniki sukcesu oraz bariery w procesie implementacji, zwraca się uwagę na konieczność modyfikacji koncepcji i metod procesowych oraz dostosowania ich do kontekstu organizacyjnego i kulturowego działania szkół wyższych. Podaje się również przykłady wielu zakończonych sukcesem wdrożeń, co potwierdza tezę, że zarządzanie procesowe może stać się użytecznym podejściem do restrukturyzacji szkół wyższych. Badacze wskazują jednak, że krytycznie ważną determinantą sukcesu zmian w systemie zarządzania szkołą wyższą jest zaangażowanie kierownictwa uczelni oraz pracowników, zmiana kultury organizacyjnej, a także wsparcie podejmowanych inicjatyw restrukturyzacji procesowej odpowiednimi zasobami. Nieodpowiednie wdrażanie zmiany prowadzi do marnotrawstwa zasobów, wdrażania zmiany dla samej zmiany, dalszej centralizacji i biurokratyzacji, formalizacji, zniechęcenia pracowników, a także podejmowania krótkoterminowych decyzji. Brak podejścia holistycznego powoduje, że restrukturyzacja jest fragmentaryczna i dotyczy przede wszystkich procesów dydaktycznych oraz naukowo-badawczych, nie wzmacnia się trzonu administracyjnego uczelni (co jest warunkiem realizacji koncepcji uniwersytetu przedsiębiorczego) (Yokoyama 2006: 523). Brak powiązania podejścia procesowego ze zmianą kultury organizacyjnej obniża trwałość efektów restrukturyzacji oraz nie przyczynia się do doskonalenia procesów w szkole w długiej perspektywie (Radnor, Walley, Stephens i Bucci 2006).

Nadal istnieje niewiele opracowań teoretycznych i badań dotyczących uwarunkowań, szans i barier wdrażania podejścia procesowego w uczelniach, co wskazuje na lukę badawczą w tym zakresie. Należy pogłębić badania nad specyfiką wdrażania podejścia procesowego w organizacjach publicznych, jakim są szkoły wyższe, szczególnie badania systemów zarządzania, struktur organizacyjnych oraz kultury organizacyjnej. Brakuje kompleksowych badań na gruncie polskiego szkolnictwa wyższego w zakresie możliwości wykorzystania metod i technik zarządzania procesami. Tematyka ta jest podejmowana, ale są to badania bardzo rozproszone ze względu na swoją problematykę, np.: jakość przywództwa i jakość zarządzania w TQM (Wawak 2012), zarządzanie strategiczne (Leja 2013), outsourcing (Maciąg 2011b), benchmarking procesowy (Woźnicki 2012), zarządzanie jakością według

\footnotetext{
${ }^{12}$ http://www.efficiencyexchange.ac.uk/8535/improving-higher-education-efficiency-sharedservices/ [12.09.2016].
} 
ISO 9001 (Piasecka 2011). Brakuje też kompleksowych opracowań ujmujących systemy zarządzania procesowego w aspekcie społecznym i kulturowym, technicznym i organizacyjnym, jak również badań w zakresie oceny dojrzałości procesowej szkół wyższych, szczególnie szkół, które wdrożyły system zarządzania jakością zgodny z normą ISO 9001.

\section{Podsumowanie}

Przeprowadzona analiza pozwala twierdząco odpowiedzieć na postawione w opracowaniu pytanie. Podejście procesowe jest koncepcją zarządzania, która ma potencjał skutecznego wspierania kierownictwa uczelni w realizacji jej celów strategicznych i operacyjnych w zakresie implementacji nowych paradygmatów zarządzania usługami publicznymi oraz modelu uniwersytetu przedsiębiorczego. Wskazuje się na przydatność zastosowania w praktyce działania szkół koncepcji i metod zarządzania opartych na podejściu procesowym, takich jak: TQM, zarządzanie jakością (m.in. norma ISO 9001), Lean Management, Six Sigma, reengineering, benchmarking, outsourcing czy centra usług wspólnych. Należy jednak mieć na uwadze liczne ograniczenia natury organizacyjnej, technicznej i kulturowej, wynikające z jednej strony z mocno zakorzenionej idei uniwersytetu liberalnego, $\mathrm{z}$ drugiej - z biurokratycznego paradygmatu zarządzania usługami publicznymi. Sukces zmiany w systemie organizacyjno-technicznym uczelni jest zdeterminowany przede wszystkim zmianami w kulturze organizacyjnej szkoły.

Z uwagi na złożoność, rozległość i wielowymiarowość podejmowanych zagadnień $\mathrm{w}$ artykule starano się zwrócić uwagę na najistotniejsze argumenty przytaczane w dyskusji na temat wykorzystania podejścia procesowego w modernizacji uczelni. Problematyka ta jest przedmiotem dalszych badań teoretycznych i aplikacyjnych.

\section{Literatura}

Anthony, S. G. (2013). The challenges of Lean Sigma Leadership. W: Enhancing Process Efficiency and Effectiveness in Higher Education Using Lean Six Sigma. Proceedings of First International Conference on Lean Six Sigma for Higher Education. 24-25 $5^{\text {th }}$ June, Glasgow, Scotland, UK (materiał elektroniczny).

Antonowicz, D. (2005). Uniwersytet przyszłości. Wyzwania i modele polityki. Warszawa: Instytut Spraw Publicznych.

Antony, J. (2004). Some pros and cons of six sigma: an academic perspective. The TQM Magazine. 16(4): 303-306.

Arena, M., Arnaboldi, M., Azzone, G., Carlucci, P. (2009). Developing a Performance Measurement System for University Central Administrative Services. Higher Education Quarterly. 63(3): 237-263. 
Azziz, R., Implementing shared services in higher education. https://www.universitybusiness.com/article/shared-services [12.09.2016].

Balzer, W.K. (2010). Lean Higher Education. New York: CRP Press. Francis \& Taylor.

Bandyopadhyay, J.K., Lichtman, R. (2007). Six Sigma Approach to Quality and Productivity Improvement in an Institution for Higher Education in the United States. International Journal of Management. 24(4): 802-807.

Bayraktar, E., Tatoglu, E., Zaim, S. (2008). An instrument for measuring the critical factors of TQM in Turkish higher education. Total Quality Management. 19(6): 551-574.

Bhat, K.S., Rajashekhar, J. (2009). An empirical study of barriers to TQM. Implementation in Indian industries. The TQM Magazine. 21(3): 261-272.

Bonstingl, J.J. (1995). Szkoły jakości. Wstęp do TQM w edukacji. Warszawa: CODN.

Bulchand-Gidumal, J., Melian-Gonzalez, S. (2010). Redesign of the IS/ICT help desk at a Spanish public university. Higher Education. 60: 205-216.

Campatellia, G., Cittib, P., Meneghina, A. (2011). Development of a simplified approach based on the EFQM model and Six Sigma for the implementation of TQM principles in university administration. Total Quality Management. 22(7): 691-704.

Chalaris, I., Chalaris, M., Gritzalis, S., Belsis, P. (2015). Process' Standardization and Change Management in Higher Education. The case of TEI of Athens, International Conference on Integrated Information (IC-ININFO 2014, AIP Conf. Proc. 1644, 263270). Madrid: AIP Publishing.

Davenport, T.H. (2008). Foreword. W: J. Jetson, J. Nelis (red.). Business Process Management. Practical Guidelines to Successful Implementation (XIV-XVIII). Oxford: Elsevier.

Davies, J. (2000). Cultural Change in Universities in the Context of Strategic and Quality Initiatives. W: P. Tabatoni, J. Davies, A. Barblan, Strategic Management and Universitie's Institutional Development (12-23). Genewa - Bruksela: EUA.

Douglas, A., Douglas, J., Antony, J. (2013). Gold in the Mine: Recognising Waste in UK HEIs using Lean Thinking. W: Enhancing Process Efficiency and Effectiveness in Higher Education Using Lean Six Sigma. Proceedings of First International Conference on Lean Six Sigma for Higher Education. 24-25 th June, Glasgow, Scotland, UK (material elektroniczny).

Goranczewski, B. (2011). Zarządzanie jakością w uczelni wyższej. Ujęcie holistyczne. Prace Naukowe Wyższej Szkoły Bankowej w Gdańsku. 12: 339-357.

Goranczewski, B. (2013). Standaryzacja jako podstawowa determinanta jakości usługi edukacyjnej. Prace Naukowe Wyższej Szkoły Bankowej w Gdańsku. 24: 161-178.

Grajewski, P. (2007). Organizacja procesowa. Projektowanie i konfiguracja. Warszawa: PWE.

Grajewski, P. (2012). Procesowe zarządzanie organizacją. Warszawa: PWE.

Grudzewski, W.M., Hejduk, I.K., Sankowska, A., Wańtuchowicz, M. (2010). Sustainability $w$ biznesie czyli przedsiębiorstwo przyszłości. Zmiany paradygmatów i koncepcji zarządzania. Warszawa: Poltext.

Hammer, M., Champy, J. (1997). Reengineering the corporation: a manifesto for business revolution. London: Nicholas Brealey Publishing.

Hamrol, A. (2007). Zarządzanie jakością z przykładami. Warszawa: Wyd. Naukowe PWN. 
http://www.efficiencyexchange.ac.uk/8535/improving-higher-education-efficiencyshared-services/ [12.09.2016].

http://www.efqm.pl/ [16.09.2016].

http://www.leanhehub.ac.uk [16.09.2016].

Jones, O. (2013). How can Higher Education institutions develop and sustain process improvement capability: An action research proposal. W: Enhancing Process Efficiency and Effectiveness in Higher Education Using Lean Six Sigma. Proceedings of First International Conference on Lean Six Sigma for Higher Education. 24-25 $5^{\text {th }}$ June, Glasgow, Scotland, UK (materiał elektroniczny).

Kerr, G., Hosie, P. (2013). Strategic Avoidance: Can Universities Learn from Other Sectors? Australian Universities' Review. 55(1): 59-65.

Kukreja, A., Ricks, J.M. Jr., Meyer, J.A. (2009). Using Six Sigma for Performance Improvement in Business Curriculum: A Case Study. Performance Improvement. 48(2): 9-25.

Kuźmicz, K. (2015). Benchmarking procesowy jako instrument doskonalenia zarządzania uczelniq. Warszawa: Wolters Kluwer Polska.

Kwiek, M. (2015). Uniwersytet $w$ dobie przemian. Warszawa: Wyd. Naukowe PWN.

Leja, K. (2013). Zarzq̨dzanie uczelniq̨. Koncepcje i współczesne wyzwania. Warszawa: Wolters Kluwer Polska.

Lisiecka, K., Maciąg, J. (2007). Karol Adamiecki współtwórcą podstaw nauki organizacji i zarządzania procesem kształtowania jakości produktów. W: E. Skrzypek (red.). Wielcy twórcy jakości w Polsce i na świecie. Lublin: Wyd. Uniwersytet M. Curie-Skłodowskiej.

Maciąg, J. (2011a). Ocena systemu zapewnienia jakości kształcenia w szkole wyższej. Katowice: Wyd. AWF.

Maciąg, J. (2011b). How can an institution of higher education become lean? Methods of higher school restructuring. W: Positive Futures for higher education: connections, communities and criticality Conference Papers Society for Research into Higher Education. Newport, Great Britain. http://www.srhe.ac.uk/conference2011/abstracts/0193. pdf [16.09.2016].

Maciąg, J. (2013). Methods of quality management system efficiency measurement in HEIs. FICL6б. W: Enhancing Process Efficiency and Effectiveness in Higher Education Using Lean Six Sigma. Proceedings of First International Conference on Lean Six Sigma for Higher Education. 24-25 $5^{\text {th }}$ June, Glasgow, Scotland, UK (materiał elektroniczny).

Maciąg, J. (2016a). Uwarunkowania wdrożenia koncepcji Lean Service w polskich szkołach wyższych. Zarządzanie Publiczne. 33(1): 51-64.

Maciag, J. (2016b). The determining role of organizational culture in the implementation of the lean management concept as examplified by Polish universities. Lean in Higher Education Conference 2016, University of Stirling, 1-3.11.2016, Stirling, Wielka Brytania. http://ruj.uj.edu.pl/xmlui/bitstream/handle/item/35320/UJ_EN\%20Maciag\%20 Lean\%20Culture.pdf?sequence=1\&isAllowed=y (dokument elektroniczny).

Nicholls, M.G. (2007). The Development of a Benchmarking Methodology to Assist in Managing the Enhancement of University Research Quality. Higher Education Quarterly. 61(4): 539-562. 
Osseo-Asare, A.E., Longbottom, D. (2002). The need for education and training in the use of the EFQM model for quality management in UK higher education institutions. Quality Assurance in Education. 10(1): 26-36.

PN-EN ISO 9000:2015 Systemy zarządzania jakością - Podstawy i terminologia (2016). Warszawa: PKN.

PN-EN ISO 9001:2015 Systemy zarządzania jakością - Wymagania (2016). Warszawa: PKN.

Piasecka, A. (2011). Wybrane aspekty zarządzania jakością w szkole wyższej. Lublin: Wyd. Uniwersytetu Marii Curie-Skłodowskiej.

Process Classification Framework version 6.1.1. American Quality Productivity Center http://www.apqc.org/knowledge base/download/313690/Ko5162_PCF_Ver_6\%201_ 1.pdf [7.02.2015].

Radnor, Z., Bucci, G. (2011). Analysis of Lean Implementation in UK Business Schools and Universities. Raport dla Association for Business Schools. https://www.york.ac.uk/ad$\mathrm{min} / \mathrm{po} /$ processreview/ABS\%20Final\%2oReport\%20final.pdf [16.09.2016].

Radnor, Z., Walley, P., Stephens, A., Bucci, G. (2006). Evaluation of the Lean Approach to Business Management and Its Use in the Public Sector. Scottish Executive Social Research, Crown Copyright.

Sherr, L.A., Lozier, G.G. (1991). Total quality management in higher education. New Directions for Institutional Research. 71: 3-11.

Suárez-Barraza, M.F., Smith, T., Dahlgaard-Park, S.M. (2012). Lean Service: A literature analysis and classification. Total Quality Management. 23(4): 359-380.

Sześciło, D. (2015). Samoobstugowe państwo dobrobytu, Warszawa: Scholar.

Tarí, J.J., Dick, G.P.M. (2012). A Review of Quality Management Research in Higher Education Institutions. BAM 2012 Cardiff Conference Proceedings.

Tarı, J.J., Madeleine, C. (2012). Introducing management models in service organisations in developed and developing countries. The Service Industries Journal. 32(5): 789-806.

Thomas, A., Francis, M., Fisher, R., Chilton, K. (2013). Can Higher Education Lean Itself Up? Can the Further Education Sector show us the way? W: Enhancing Process Efficiency and Effectiveness in Higher Education Using Lean Six Sigma. Proceedings of First International Conference on Lean Six Sigma for Higher Education. 24-25 ${ }^{\text {th }}$ June, Glasgow, Scotland, UK (materiał elektroniczny).

Tjahjono, B. i in. (2010). Six Sigma: a literature review. International Journal of Lean Six Sigma. 1(3): 216-233.

Ustawa z dnia 27 sierpnia 2009 r. o finansach publicznych, Dz.U. nr 157, poz. 1240.

Veiga, A., Rosa, M.J., Dias, D., Amaral, A. (2013). Why is it Difficult to Grasp the Impacts of the Portuguese Quality Assurance System? European Journal of Education. 48(3): 454-470.

Wasilewski, L. (1998). Do czego służy TQM? Problemy Jakości. 3: 2-5.

Wawak, T. (2011). Wyzwania zarządzania jakością w szkołach wyższych. Kraków: Wyd. Uniwersytetu Jagiellońskiego.

Wawak, T. (2012). Jakość zarządzania w szkołach wyższych. Kraków: Wyd. Uniwersytetu Jagiellońskiego. 
Woźnicki, J. (red.) (2012). Benchmarking w szkolnictwie wyższym. Wybrane problemy: Elastyczność, e-learning, wewnętrzne systemy zapewniania jakości w systemie ksztatcenia, gospodarka zasobami dla poprawy produktywności i konkurencyjności - kontrola zarządcza. Warszawa: Fundacja Rektorów Polskich.

Wilson, T. (2015). Ratemyprofessors.com Evaluations and External Benchmarks of Accounting Program Quality. Academy of Educational Leadership Journal. 19(1).

Yeung, S.M. (2013). Applying Six Sigma into Curriculum Design for Creating Value - Fulfilling Accreditation Requirements with Learning Outcomes Measured. W: Enhancing Process Efficiency and Effectiveness in Higher Education Using Lean Six Sigma. Proceedings of First International Conference on Lean Six Sigma for Higher Education. 24-25 th June, Glasgow, Scotland, UK (material elektroniczny).

Yokoyama, K. (2006). Entrepreneurialism in Japanese and UK universities: Governance, management, leadership, and funding. Higher Education. 52: 523-555.

Yorkstone, S. (2013). Leaning Universities Old and New: A comparative case study on the implementation of Lean Thinking in Universities Ancient and Modern, from the perspective of a practitioner. W: Enhancing Process Efficiency and Effectiveness in Higher Education Using Lean Six Sigma. Proceedings of First International Conference on Lean Six Sigma for Higher Education. 24-25 ${ }^{\text {th }}$ June, Glasgow, Scotland, UK (materiał elektroniczny).

Yu, K.-T., Ueng, R.-G. (2012). Enhancing teaching effectiveness by using the Six-Sigma DMAIC model. Assessment \& Evaluation in Higher Education. 37(8): 949-961.

\title{
Implementation of process approach to management of public higher education institutions - challenges of theory and practice
}

\begin{abstract}
Challenges for university in XXI century are: quality of services, effectiveness, efficiency and flexibility. To meet these expectations HEIs started a restructuring of a management system using a modern concepts and methods based on process approach. There are: TQM, EFQM, ISO 9001, Lean Management, Six Sigma, reengineering, benchmarking, outsourcing, shared service centers. The purpose of the paper is to present the theoretic and practical achievements in implementation of concepts and methods based on a process approach. The paper is based on literature analysis and own research. The results of analysis is presentation of the main issues taken in research on a process management, reasons and barriers of its implementation and the research gap in these area.
\end{abstract}

KEYWORDS: process approach, universities, New Public Management, good governance

CYTOWANIE: Maciąg, J. (2016). Zastosowanie podejścia procesowego w zarządzaniu publicznymi szkołami wyższymi - wyzwania teorii i praktyki. Nauka i Szkolnictwo Wyższe. 1(47): 163-180. DOI: 10.14746/nisw.2016.1.6. 